\title{
Dejavniki kariernega prehoda v poklic vzgojitelja za delo z otroki s posebnimi potrebami
}

\author{
Andrej Kociper \\ Dom Antona Skale Maribor \\ andrej.kociper@gmail.com
}

\begin{abstract}
V prispevku predstavljamo dejavnike, ki so prispevali h kariernemu prehodu v poklic vzgojitelja za delo z otroki s posebnimi potrebami, ki imajo motnjo $v$ duševnem razvoju. V kvalitativni raziskavi, ki smo jo opravili z metodo poklicne biografije, je sodelovalo devet vzgojiteljev. Med ključnimi dejavniki prehoda so bili identificirani: zaposlitev za nedoločen čas, družbena pomoč in altruizem, izvajanje pomoči ljudem v stiskah ali v težavah. Raziskava je pokazala, da med vzgojitelji obstajajo razlike glede na njihovo delovno dobo. Mlajši vzgojitelji ocenjujejo in zaznavajo večji učinek dejavnikov, izhajajoč iz nekaterih socialnih situacij, medtem ko starejši vzgojitelji bolj izpostavljajo varnost zaposlitve. Svoje profesionalne kompetence so si nekateri, glede na že doseženo pedagoško izobrazbo, morali nadgraditi z vključitvijo v dopolnilna izobraževanja defektologije ali specialne pedagogike. Nekateri so se vključili v podiplomski študijski program inkluzivne pedagogike.
\end{abstract}

Ključne besede: karierni prehod, profesionalni razvoj, vzgojitelj, otrok s posebnimi potrebami, metoda poklicne biografije

\section{Uvod}

Prehod iz enega pedagoškega poklica v drugega (t. i. karierni prehod) ${ }^{1}$ ali pa samo spreminjanje vloge znotraj samega poklica je lahko vsestransko pozitivna izkušnja, če je posameznik nanjo ustrezno pripravljen. Ta raziskava preučuje dejavnike, ki so bili prisotni pri udeležencih raziskave ob njihovem kariernem prehodu v poklic vzgojitelja za delo z otroki in mladostniki s posebnimi potrebami, ki imajo motnjo v duševnem razvoju. ${ }^{2}$ Ti otroci in mlado-

\footnotetext{
${ }^{1}$ Izraz karierni prehod se je razvil na podlagi dolgoletnih pomembnih in prelomnih raziskav in teoretičnega dela o procesu poklicnega razvoja. Donald Super je od petdesetih let prejšnjega stoletja dalje obširno pisal o stopnjah poklicnega razvoja, pri čemer je vsaka stopnja pomenila poseben »prehod« na posameznikovi poklicni poti. Te faze zajemajo celotno življenje in vključujejo vse dogodke, povezane s kariero, od posameznikove prve zaposlitve do upokojitve ali popolne prekinitve dela (Super 1957).

${ }^{2} \mathrm{~V}$ Kriterijih za opredelitev vrste in stopnje primanjkljajev (Zavod Republike Slovenije za šolstvo 2015) je motnja v duševnem razvoju opredeljena kot nevrološko pogojena razvojna motnja,
} 
stniki so namreč popoldan vključeni v vzgojni program domov, kjer z njimi delajo vzgojitelji (Strokovni svet Republike Slovenije za splošno izobraževanje 2011). Osnovni namen je približati razumevanje položaja pedagoških delavcev, ki zaradi poklicne spremembe prehajajo iz enega poklica v drugega, in nakazati izzive nenehnega poklicnega učenja in razvoja ter spremembe odnosa do profesionalnega razvoja.

Raziskovalci s številnih področij, vključno z upravljanjem človeških virov, organizacijskim vedenjem, mednarodnim upravljanjem in podjetništvom, so preučevali posebne vrste prehodov, ki se zgodijo med posameznikovo poklicno kariero. Opravili so preglede kariernih prehodov, kot so vstop v organizacijo (Ellis idr. 2015; Fang, Duffy in Shaw 2011), fluktuacija (Bilgili idr. 2017; Hom idr. 2017), napotitve v tujino (Baruch, Altman in Tung 2016; Kraimer, Bolino in Mead 2016; Takeuchi 2010), upokojitev (Beehr 2014; Wang in Shi 2014), odločitev žensk za vstop in izstop s trga dela (Zimmerman in Clark 2016), izguba zaposlitve (Gowan 2014; Van Dierendonck in Jacobs 2012) in prehod od zaposlenega v podjetju do podjetnika (Terjesen, Hessels in Li 2016). Raziskave so omogočile boljše razumevanje posebnosti kariernih prehodov, pri čemer je karierni prehod opredeljen kot obdobje, $v$ katerem posameznik bodisi zamenja vlogo (prevzame drugačno objektivno vlogo) bodisi spremeni usmerjenost v že obstoječo vlogo (Louis 1980 v Sullivan in Al Ariss 2021).

Ljudje, ki živijo in delajo na različnih področjih, se socializirajo vsak na svoj način, zato bodo imeli tudi na delovnih mestih povsem drugačen odnos do učenja, razlikovali se bodo pri soočanju zživljenjskimi situacijami in imeli drugačen pristop k učnim možnostim (Brown in Bimrose 2014). Med temeljnimi dejavniki, ki pomembno vplivajo na posameznikove ravnanje in prepričanja, sta potek oblikovanja poklicne identitete ter potek poklicne socializacije.

Savickas (2015) opozarja, da je za odzivanje na zapletene delovne in poklicne potrebe 21. stoletja potreben drugačen pristop tudi pri kariernemu svetovanju. Med drugim predlaga pripovedni pristop, ki namesto testov uporablja življenjske zgodbe, preko katerih posamezniki prepoznajo svojo realnost, vloge in zmožnosti, ki so jih oblikovali v družbenem kontekstu.

Nekateri avtorji (Schlesinger in Daley 2016) hkrati poudarjajo, da se vse bolj

ki se pojavi pred 18. letom starosti. Zanjo so značilne znatne omejitve $v$ intelektualnem delovanju in prilagojenem vedenju ter se kaže $v$ nižjih konceptualnih, socialnih in praktičnih prilagoditvenih spretnostih. Osebe $z$ motnjami v duševnem razvoju imajo premalo razvit intelekt ali zmanjšane učne sposobnosti, njihov motorični in jezikovni razvoj pa sta motena. Pogosto imajo težave pri socialnih in komunikacijskih spretnostih. Njihove sposobnosti so tudi trajno poškodovane, kar vodi v počasnejši razvoj. Glede na stopnjo motnje v duševnem razvoju ločimo otroke $z$ lažjo, zmerno, težjo in težko motnjo v duševnem razvoju. 
uveljavlja kontekstualno-konstruktivističen pristop h kariernemu razvoju, ki posameznika spodbuja k samoraziskovanju, uporabo strategij, ki integrirajo iskanje stabilnosti in rezilientnost, ki nastajajo zaradi mnogih sprememb, tveganj in naključij na trgu dela. Posameznik si danes mora pri kariernem odločanju postavljati tiste odločitve, ki so najbolj logične za realizacijo (Pryor idr. 2008).

Odgovornost za upravljanje kariere se je v zadnjem desetletju prenesla z organizacije na posameznika. Vzorci kariere so zato vse pestrejši in bolj večsmerni. Premiki navzgor so le en možen vidik oz. smer kariere. V karieri je vse več lateralnih premikov in tudi premikov navzdol. Pojem kariera se zato širi tudi zunaj okvirov delovnih izkušenj, in sicer na področje prostega časa ali nezaposlenosti. Na odločitve v zvezi s kariero vplivajo družina in druga okolja, v katerih posameznik zadovoljuje svoje potrebe (Brečko 2006 v Javrh 2011).

Naša raziskava temelji na poklicni biografiji, njen glavni cilj pa je bil ugotoviti dejavnike, ki jih je potrebno upoštevati pri odločitvi za karierni prehod $v$ poklic vzgojitelja za delo z otroki s posebnimi potrebami.

$\checkmark$ zadnjem času se poklicna biografija vse bolj uveljavlja kot pomemben in drugačen pristop v kvalitativnem raziskovanju. Pri nas pa je, predvsem na pedagoškem področju, še dokaj nepoznana in izredno malo uporabljena (Cencič 2001; Javornik Krečič 2007 V Štemberger in Vesel 2015). Biografija nam ponuja načine za poglobljeno dokumentiranje posameznih zgodb v družbenem kontekstu skozi čas in je primerna za raziskovanje širokega spektra pojavov, kar kaže metodološko moč tega pristopa (Merrill in West 2009 v Barabasch in Merrill 2014; Lončar, Šuljug Vučica in Bubić 2019).

\section{Delo vzgojitelja otrok s posebnimi potrebami}

$V$ »Navodili h kurikulumu za vrtce v programih s prilagojenim izvajanjem in dodatno strokovno pomočjo za otroke s posebnimi potrebam « (Strokovni svet Republike Slovenije za splošno izobraževanje 2003) je delo vzgojitelja, ki dela z otroki s posebnimi potrebami, opredeljeno kot eno najodgovornejših nalog, saj sodeluje pri vzgoji otrok s posebnimi potrebami in ob tem nosi polno poklicno ter osebno odgovornost. Da je pri tem lahko uspešen, se od njega pričakuje veliko znanja, izkušenj, osebna angažiranost in timsko delo. Vzgojitelj sodeluje pri večini nalog glede otroka s posebnimi potrebami, ki je vključen v skupino. Ob tem nosi poklicno in osebno odgovornost. $V$ proces pomoči takšnemu otroku vstopa pri neposrednem vsakodnevnem delu z njim, pri sodelovanju s starši in z različnimi strokovnjaki. Vsa ta področja od njega zahtevajo več znanja, izkušenj in tudi osebne angažiranosti. Zato potrebuje vso strokovno podporo, tako specialnih pedagogov/defektologov in 
drugih strokovnih delavcev, ki delajo z otrokom, kakor tudi različnih zunanjih sodelavcev, svetovalne službe, vodstvenih delavcev in ravnatelja.

Danes lahko pedagoški poklic kakovostno, suvereno in ponosno opravlja le nekdo, ki dobro pozna strokovno vsebino področja, ki je izvrstno izobražen na didaktičnem področju, ki prepozna posameznikove potrebe in je tudi motiviran za to, da mu prilagodi način dela. Dober pedagoški delavec je tisti, ki se je pripravljen učiti vse življenje in je pripravljen na to, da pedagoški poklic postane njegov način življenja (Vogrinc 2019).

Sodobni vzgojitelj potrebuje danes za svoje profesionalno delovanje širše kompetence, kot so: prizadevanje za spremembe, odprta komunikacija in omogočanje vzajemnega dialoga, kritična refleksija, zmožnost soočanja z zapletenimi vprašanji $z$ različnih zornih kotov in učenje s perspektive različnih nasprotujočih si pogledov (Peeters in Vandenbroeck 2011 V Valenčič Zuljan in Blanuša Trošelj 2014).

Cenčičeva in Čagranova (2002) menita, da naj se za vzgojiteljski poklic premišljeno odloči osebnostno zrela oseba, $z$ realističnim pogledom na svet in nekdo, ki se zaveda, da bo delal z otroki v najzahtevnejšem in najobčutljivejšem razvojnem obdobju.

Razloge za izbiro pedagoškega poklica sta razdelili na pet skupin, in sicer:

1. altruistični razlogi (notranji dejavnik, motivacija, npr. pomagati drugim);

2. samouresničitveni razlogi (notranji dejavnik, težnja po osebnostni in profesionalni rasti, koristnosti in vplivnem delovanju);

3. alternativni razlogi (zunanji dejavnik, motivacija, npr. neizpolnjeni pogoji vpisa po lastni želji);

4. razlogi iz inspiracije in stereotipov (zunanji dejavnik, želja staršev po akademski izobrazbi, zastopanje tega poklica v družini, poklic za ženske idr.);

5. materialni razlogi (zunanji dejavniki, npr. krajši delovni čas, počitnice, možnost izobraževanja, finančna varnost, dober osebni dohodek).

Vzgojitelji so zato, podobno kot drugi pedagoški delavci, postavljeni pred številne poklicne izzive. Od njih se danes pričakuje kakovostno ravnanje na več področjih, od poznavanja otrok in dela z njimi do sodelovanja s starši in z družbeno skupnostjo (Valenčič Zuljan in Blanuša Trošelj 2014). V strokovni literaturi je kot eden glavnih razlogov za opravljanje pedagoškega poklica navedeno veselje do dela $z$ otroki. $K$ tej odločitvi pa lahko stimulativno prispeva še primeren zaslužek (Lepičnik Vodopivec 2007). 


\section{Problem}

Posameznik se v svojem življenju mnogokrat sooča z izzivi na poklicnih in zaposlitvenih križiščih, ki terjajo nova znanja in veščine za uspešno participacijo na prožnem trgu dela. Vmes pa so zahtevni prehodi, ki ne zadevajo samo prehoda na drugo delo, temveč tudi življenjska obdobja med mladostjo in odraslostjo. Na odločitve v zvezi s poklicem lahko pomembno vplivajo: ustvarjanje družine, samostojno življenje, soočanje $z$ boleznijo ali invalidnostjo, $s$ starostjo ali z izgubo dela, pozitiven odnos do lastnega profesionalnega razvoja, odnos do drugih, do sprememb pri delu ter do sprememb pri sebi ipd. (Brečko 2006 v Javrh 2011; Drobnič 2012).

$\checkmark$ raziskavi s poklicno biografijo, kjer spoznamo osebne perspektive ter poskušamo čim natančneje ujeti razmišljanja oseb v raziskovalnih situacijah, je v našem primeru sodelovalo devet udeležencev. K sodelovanju smo jih povabili štirinajst, vendar vsi niso bili pripravljeni sodelovati. Tako majhno število zadostuje, saj sta osnovna pogoja sodelovanja prostovoljnost in pripravljenost za resnejši vpogled vase in $v$ svoje delo. To pa zahteva več časa in poguma (Sagadin 1991 v Javornik Krečič 2008).

Pregled relevantne literature s pomočjo Google Scholar je vključeval raziskave z metodo poklicne biografije in raziskave dejavnikov ter vrednot pri udejanjanju kariernih odločitev. Ob pregledu znanstvenih objav je mogoče opaziti, da se s to tematiko obravnava predvsem vzgojitelje v predšolskem okolju (npr. Hmelak in Lepičnik Vodopivec 2012; Cenčič in Čagran 2002), manj pa profesionalni razvoj vzgojiteljev, ki delajo z otroki in mladostniki z motnjami v duševnem razvoju. Glede na interese raziskovalcev je poklicno biografijo mogoče gledati z različnih vidikov, in sicer kot teoretično-metodološki okvir pa tudi kot raziskovalno metodo.

$\checkmark$ naši raziskavi nas je zato zanimalo, kateri so tisti ključni dejavniki, ki so udeležence raziskave pripeljali do kariernega prehoda v poklic vzgojitelja za delo $z$ otroki s posebnimi potrebami, ki imajo motnjo v duševnem razvoju.

\section{Metodologija raziskave}

Osnovni raziskovalni metodi sta bila deskriptivna metoda empiričnega pedagoškega raziskovanja in kvalitativni raziskovalni pristop.

\section{Vključeni v raziskavo}

Udeležencev raziskave je bilo devet neslučajnostno priložnostno izbranih vzgojiteljev, ki imajo delovne izkušnje $z$ delom z otroki s posebnimi potrebami, ki imajo motnjo v duševnem razvoju. Vzgojitelji so bili osebno vabljeni 
Preglednica 1 Podatki o udeležencih

\begin{tabular}{|c|c|c|c|c|c|}
\hline (1) & (2) & (3) & (4) & (5) & (6) \\
\hline Janja & 9 let & $\begin{array}{l}\text { univ. dipl. soc. ped., } \\
\text { mag. prof. inkl. ped. }\end{array}$ & $\mathrm{VII} / 2$ & vzgojiteljica v vzgojnem zavodu & da \\
\hline Vanja & 2 leti & univ. dipl. pedagog & $\mathrm{VII} / 2$ & $\begin{array}{l}\text { v domovih za otroke in mladostnike } \\
\text { s posebnimi potrebami }\end{array}$ & ne \\
\hline Mojca & 36 let & učiteljica RP & $\mathrm{Vl} / 1$ & učitelj razrednega pouka & ne \\
\hline Matjaž & 20 let & $\begin{array}{l}\text { prof. nem., } \\
\text { mag. prof. inkl. ped. }\end{array}$ & $\mathrm{VII} / 2$ & učitelj za učno pomoč & ne \\
\hline Niko & 2 leti & mag. zgodovine & $\mathrm{VII} / 2$ & vzgojitelj v vzgojnem zavodu & ne \\
\hline Nataša & 2 leti & $\begin{array}{l}\text { prof. šport. vzg., } \\
\text { mag. prof. inkl. ped. }\end{array}$ & $\mathrm{VII} / 2$ & $\begin{array}{l}\text { v domovih za otroke in mladostnike } \\
\text { s posebnimi potrebami }\end{array}$ & ne \\
\hline David & 35 let & $\begin{array}{l}\text { učitelj zgodovine } \\
\text { in sociologije }\end{array}$ & $\mathrm{Vl} / 1$ & $\begin{array}{l}\text { v domovih za otroke in mladostnike } \\
\text { s posebnimi potrebami }\end{array}$ & ne \\
\hline Helena & 17 let & prof. mat. & $\mathrm{VII} / 2$ & $\begin{array}{l}\text { v domovih za otroke in mladostnike } \\
\text { s posebnimi potrebami }\end{array}$ & ne \\
\hline Marija & 10 let & $\begin{array}{l}\text { prof. slov., } \\
\text { mag. prof. inkl. ped. }\end{array}$ & $\mathrm{VII} / 2$ & čistilka & ne \\
\hline
\end{tabular}

Opombe (1) ime, (2) delovna doba, (3) izobrazba, (4) stopnja izobrazbe, (5) prva zaposlitev, (6) izpolnjeval izobrazbene pogoje ob zasedbi delovnega mesta.

k sodelovanju. Udeležence smo zaradi zagotavljanja anonimnosti poimenovali z izmišljenimi imeni. V analizi smo jim dopisali le delovno dobo.

\section{Postopek zbiranja podatkov}

Za našo raziskavo smo zbirali podatke s pomočjo pisne komunikacije preko osebne elektronske pošte $v$ obliki zapisanega besedila. Udeležencem raziskave smo predhodno posredovali navodila za pisanje besedila. To metodo so v svojih raziskavah že uporabljali Edwardsova in Talboltova (1994 v Javornik Krečič 2008) ter Graham (1989 v Javornik Krečič 2008).

Udeleženci so narisali reko poklicnega razvoja, napisali poklicno biografijo ter opisali pomemben dogodek. Vzgojitelji so v raziskavi sodelovali prostovoljno. Podatke smo zbirali februarja 2021. Zaradi zimskih počitnic in razglašene epidemije (delo vzgojiteljev od doma - na daljavo) smo nekaterim termin prestavili in zbiranje podatkov zaključili 15. marca 2021.

\section{Pripomočki}

Kvalitativna raziskava s poklicno biografijo nam pomaga ugotoviti, kaj je tisto, kar dela dobrega profesionalca, hkrati pa udeležencem raziskave omogoča samorefleksijo o njihovem profesionalnem in osebnostnem razvoju. Javornik Krečičeva (2008) navaja, da so v zadnjem obdobju raziskave s pomočjo 
poklicne biografije precej razširjene, saj se preko pripovedovanja o osebnem življenju in refleksije pedagoškemu strokovnemu delavcu (učitelju ali vzgojitelju) omogoča ustvarjanje novih pomenov, ki mu omogočajo razlago, organizacijo lastnega znanja o učenju, poučevanju ter s tem spremembe v njegovi praksi, osebnem in profesionalnem razvoju. Analiza poklicne biografije nam tako daje podatke in informacije o profesionalnem razvoju z omejitvijo na posameznega udeleženca, kar ne omogoča posploševanja.

Glede na namen kvalitativnega pristopa raziskave smo udeležencem raziskave posredovali pisna navodila, nekaterim osebno, večini pa po predhodnem dogovoru preko elektronske pošte. Navodila za pisanje smo razdelili na tri dele.

V prvem delu so vzgojitelji dobili opis, kako narišejo reko svojega poklicnega razvoja (Zuzovsky 1990 v Javornik Krečič 2007; Terhart 1997 v Valenčič Zuljan 2001) in jo opremijo s posameznimi mejniki: poklicno pot so morali predstaviti in narisati kot reko z zavoji in pritoki, ki ponazarjajo pomembne zunanje in notranje dogodke ter spremembe na njihovi poklicni poti. $V$ drugem delu smo navedli, kako naj skozi samorefleksijo (poklicna biografija vzgojiteljev) opišejo, kaj vse jih je oblikovalo in pripeljalo do poklica, kakršnega opravljajo danes.

$\checkmark$ tretjem delu so morali opisati en dogodek, ki jim je predstavljal velik izziv ali stisko $v$ povezavi z nihovimi vrednotami in prepričanji in je bil pomemben pri njihovem poklicnem prehodu.

\section{Analiza podatkov}

Po opravljenem pregledu rek poklicnega razvoja, poklicne avtobiografije in pomembnega dogodka smo pripravili »zgoščen« zapis. Nekatere zbrane odgovore smo pretipkali, ostale pa kopirali iz Wordovih dokumentov. Transkripte smo pregledali, uredili, primerjali in analizirali. Navedenih podatkov nismo spreminjali. Pri analizi smo uporabili le tisti del podatkov, ki se je nanašal na raziskovalno vprašanje. Na podlagi poklicnih biografij smo povzeli skupne dejavnike, o katerih pišejo vzgojitelji v svojih poklicnih biografijah. Glede na analizo odlomkov, ki niso obsežni, smo za kriterij relevantnosti izbrali zapise, ki se pojavijo v vsaj dveh biografijah.

Kvalitativne raziskave pogosto kritizirajo zaradi pomanjkanja znanstvene strogosti in slabe utemeljenosti sprejetih metod. Prav tako so analitični postopki premalo pregledni, ugotovitve pa so zgolj zbirka osebnih mnenj in so lahko tudi rezultat pristranskosti raziskovalcev (Noble in Smith 2015). Validacijo in zanesljivost raziskave smo zato preverjali in potrdili z dobesednimi zapisi ter s prepoznavanjem opisov s strani udeležencev. 
Preglednica 2 Kategorije glede na število omemb

\begin{tabular}{lr}
\hline Kategorije & Število omemb \\
\hline Dodiplomsko izobraževanje & 9 \\
Prva zaposlitev, izkušnje z delom & 9 \\
Menjava službe, sprememba delovnega mesta & 7 \\
Prelomni dogodki, krize in druge obremenitve & 8 \\
\hline
\end{tabular}

\section{Rezultati}

Zapis biografije je odvisen od osebe, ki jo piše, njenih izkušenj in sposobnosti izražanja (Javornik Krečič 2006). V nadaljevanju so skladno z zastavljenim raziskovalnim vprašanjem predstavljeni posamezni poudarki z odlomki iz opisov poklicnih biografij. Citiranje zapisov je v prvi osebi, saj na ta način lažje začutimo odnos in doživljanje pisanja udeležencev. Rezultati so predstavljeni na osnovi cilja raziskave: ugotoviti dejavnike, ki so bili prisotni in upoštevani pri odločitvi za poklic vzgojitelja za delo z otroki s posebnimi potrebami.

Vsi, razen ene udeleženke, so bili na delovnem mestu vzgojitelja ( $v$ domu za učence) zaposleni brez ustreznih izobrazbenih pogojev. ${ }^{3}$

To dejstvo je pozneje močno usmerjalo njihovo odločitev za dodatno strokovno izobraževanje in njihov nadaljnji profesionalni razvoj. Brez tega namreč njihov uspešen prehod ne bi bil mogoč. Na podlagi poklicnih življenjepisov in skladno $z$ raziskovalnim vprašanjem smo oblikovali naslednje kategorije: dodiplomsko izobraževanje, prva zaposlitev oz. prve izkušnje z delom, menjava službe ali sprememba delovnega mesta, prelomni dogodki, krize in druge obremenitve, ki jih predstavljamo v preglednici 2.

\section{Dodiplomsko izobraževanje - odločitev za poklic}

Vsi udeleženci so zaključili enega od študijskih programov, nekateri celo isto stopnjo izobrazbe, vendar na različnih študijskih smereh. Polovica udeležencev je končala po dva študijska visokošolska programa na različnih fakultetah (npr. univ. dipl. soc. pedagog in mag. prof. inkluzivne pedagogike). Skoraj vsi pa so svojo poklicno kariero nadgrajevali z dodatnim izobraževanjem. Neka-

\footnotetext{
${ }^{3}$ Izobrazba za vzgojitelja v vzgojnem programu za otroke in mladostnike s posebnimi potrebami $v$ domovih je določena s Pravilnikom o izobrazbi vzgojiteljev in drugih strokovnih delavcev v vzgojnem programu domov za učence s posebnimi potrebami (2015). S tretjim odstavkom 99. člena Zakona o organizaciji in financiranju vzgoje in izobraževanja (2007) pa je določeno, da morajo imeti vzgojitelji v vzgojnem programu za otroke s posebnimi potrebami izobrazbo ustrezne smeri, pridobljeno po študijskem programu druge stopnje, oz. izobrazbo, pridobljeno po študijskem programu, po katerem se pridobi izobrazbo, ki v skladu z zakonom ustreza izobrazbi druge stopnje, in specialnopedagoško izobrazbo.
} 
teri od njih so že pred študijem vedeli ali začutili, da si želijo delati z otroki s posebnimi potrebami. Tako tudi Janja, Vanja, Niko in Nataša.

$V$ 2. letniku gimnazije smo pri predmetu psihologija opravili ogled vzgojnega zavoda. Takrat sem se odločila, da bom postala socialna pedagoginja, ker sem si želela nekega dne delati v tem zavodu. Po uspešno zaključeni gimnaziji sem študirala socialno pedagogiko $v$ Ljubljani. [Janja, 9 let delovne dobe]

Velik izziv mi je bilo delati z otrokom, ki je imel disleksijo, dispraksijo ter diskalkulijo. Zaradi teh začetkov sem se odločila za študij pedagogike, ker me je to veselilo. [Vanja, 2 leti delovne dobe]

Imam dobre motorične sposobnosti in gibljivost, zato me je trenerka športne gimnastike kar sama vpisala v gimnastično šolo. Takrat se je začela moja zaljubljenost $v$ šport, ki je trajala vso osnovno in srednjo šolo. Zaradi zaljubljenosti $v$ šport sem se že $v$ mladosti odločila, da bom športna učiteljica. Potem pa se je $v$ tretjem letniku Fakultete za šport zame vse spremenilo. Takoj po faksu sem se vpisala na magistrski študij inkluzivne pedagogike $v$ Mariboru. [Nataša, 2 leti delovne dobe]

Mojca in Niko si tega poklica najprej nista predstavljala ali želela, vendar sta se pozneje dodatno izobraževala, da sta lahko ostala v njem.

Po končani srednji šoli sem želela na medicinsko fakulteto, ki je bila takrat še samo $v$ Ljubljani. Mama se absolutno ni strinjala s tem. V odločanju o moji prihodnosti je bilo tudi veliko govora o finančnih stroških bivanja v Ljubljani in o dragih učbenikih. Ponovno je obveljala njena in tako sem se vpisala na Pedagoško akademijo, smer razredni pouk, $v$ Mariboru, kar je odgovarjalo predvsem staršem. Končala sem jo v roku. [Mojca, 36 let delovne dobe]

Čeprav sem po srcu in duši ter izobrazbi zgodovinar, me je delo z otroki $z$ raznimi motnjami vedno zanimalo. To me je najverjetneje navdušilo že v osnovnošolskih časih, ko me je mama večkrat vzela zraven v službo $v$ vzgojni zavod ter na razna letovanja, kjer sem lahko take otroke in mladostnike s posebnimi potrebami tudi spoznal. Vpisan sem na podiplomski študij inkluzivne pedagogike. [Niko, 2 leti delovne dobe]

Pri nekaterih se je dokončna odločitev za poklicno kariero vzgojitelja oblikovala šele ob izpolnjevanju pogojev za zaposlitev za nedoločen čas ter na podlagi delovnih izkušenj z otroki s posebnimi potrebami. 
Hitro sem ugotovil, da mi delo s to občutljivo populacijo zelo leži in da imam sposobnost nuditi pomoč in podporo otrokom in mladostnikom s posebnimi potrebami. Zaradi želje po nadaljevanju dela s to populacijo sem moral sprejeti nadaljnje odločitve, saj za to delo kot profesor nemškega jezika nisem imel ustrezne izobrazbe. Vpisal sem se na Pedagoško fakulteto v Kopru, na magistrski študij inkluzivne pedagogike, ki sem ga uspešno zaključil. [Matjaž, 20 let delovne dobe]

Po opravljeni diplomi na Pedagoški akademiji sem se konec avgusta 1986 zaposlil v domu. Ravnateljica me je sprejela na delovno mesto nočnega vzgojitelja. Pozneje sem bil razporejen na delovno mesto vzgojitelja v skupini za določen čas. Zaradi neustrezne izobrazbe in temu ustrezne pogodbe o zaposlitvi sem se moral vsako leto prijavljati na razpise za to delovno mesto. Med letoma 1991 in 1993 sem opravil defektološko dokvalifikacijo na Pedagoški fakulteti v Ljubljani in leta 1994 sem po pridobljeni ustrezni izobrazbi, leta 1994, z delodajalcem sklenil pogodbo za nedoločen čas. [David, 35 let delovne dobe]

Spomnim se, da sem že kot otrok želela postati ali učiteljica ali gledališka igralka. Dobro sem se počutila, če sem bila v središču pozornosti, rada sem javno nastopala, rada sem pomagala drugim, jih vodila, jim svetovala in jih učila. Po kar nekaj letih sem se odločila oz. zbrala motivacijo, da študij dokončam. A delovnega mesta na šoli nisem dobila. Enkrat sem po naključju govorila s kolegico iz študija, ki mi je povedala, da se je naknadno vpisala na inkluzivno pedagogiko. Pripovedovala je o tem, kako je ta študij v redu in o možnostih zaposlitve s to izobrazbo. Začela sem razmišljati, da bi morda bila to prava pot tudi zame. [Marija, 10 let delovne dobe]

Že v nižjih razredih osnovne šole sem vedela, da si želim postati učiteljica. Za študij geografije in matematike sem se odločila zato, ker so za študij matematike ponujali kadrovsko štipendijo Ministrstva za šolstvo in nekako garantirali službo. Za geografijo pa sem se odločila zato, ker me je ta predmet zanimal že iz osnovne šole. Študij je bil zelo naporen. Vendar sem ga $v$ šestih letih uspela zaključiti. [Helena, 17 let delovne dobe]

\section{Prva zaposlitev oz. prve izkušnje z delom}

Vsak, ki vstopa na trg dela, se enkrat sooča s prvo zaposlitvijo. Potrebe po vzgojiteljih za delo $z$ otroki in mladostniki s posebnimi potrebami so bile $v$ 
preteklosti precejšnje, kar pričajo tudi zapisi. Nekateri udeleženci pa so se lotevali dela na povsem drugih področjih izven svojega poklica ali pa so pričeli z delom vzgojitelja, pa čeprav so sami prihajali z drugih poklicnih področij. Tako so se, kot Marija, najprej zaposlili ali iskali prve izkušnje z delom izven pedagoškega področja.

Nisem imela dovolj motivacije, da zaključim študij. Želela sem se osamosvojiti in dobiti redno službo. Takrat mi je bilo vseeno, kakšno bo to delo, samo da se osamosvojim in postavim na svoje noge. Takrat so $v$ našem kraju odprli nov vrtec in po naključju sem dobila delovno mesto čistilke, čeprav sem se prijavila kot spremljevalka gibalno oviranemu otroku. [Marija, 10 let delovne dobe]

Ena udeleženka raziskave je po končanem študiju inkluzivne pedagogike na trgu dela nastopila delo vzgojitelja. Kot začetnik v svojem poklicu je delo vzgojitelja dobila Nataša, ki se je začela zavedati, da si odnos in ugled v kolektivu moraš zgraditi.

Ugotavljam tudi, da bi kljub mladosti in malo izkušnjam rada, da bi me sodelavci resneje obravnavali. Občutek imam namreč, da sem v svojem krogu sodelavcev razen redkih izjem izjemno nepomembna. Zmeraj sem se počutila pomembno in inteligentno. Zdaj pa svoja mnenja raje zadržujem zase, ker se mi zdi, da bodo tako ali tako naletela na posmehovanje za hrbtom ali gluha ušesa. Tudi zmotim se sedaj večkrat, kot si upam priznati. Kljub temu se poberem in poskušam znova in zopet in spet, ker imam zase sanjsko službo. [Nataša, 2 leti delovne dobe]

Nekaj udeležencev je svojo prvo zaposlitev dobilo v svojem primarnem poklicu (npr. kot socialni pedagog). Ena od teh je bila tudi Janja. Matjaževa prva zaposlitev pa je bila na srednji šoli, kjer je bil izvajalec individualne strokovne pomoči dijakom s posebnimi potrebami.

Po zaključenem zadnjem letniku študija sem se takoj zaposlila v vzgojnem zavodu, kjer sem na delovnem mestu vzgojiteljice $v$ vzgojni skupini otrok in mladostnikov $z$ vedenjskimi in s čustvenimi težavami nadomeščala delavko na porodniškem. [Janja, 9 let delovne dobe]

Kot učitelj nemškega jezika sem poučeval na srednji šoli za gostinstvo in turizem. [Matjaž, 20 let delovne dobe] 
Delo vzgojitelja je opravljalo več udeležencev, ki sprva niso izpolnjevali pogojev za to delo. Med udeleženci, ki so nastopili delo vzgojitelja brez ustreznih pogojev, so bili vsi razen Janje.

Nekaj let kasneje sem končala dokvalifikacijo, ki je bila ključni pogoj, da sem lahko dobila v domu zaposlitev za nedoločen čas. [Mojca, 36 let delovne dobe]

Kot magister zgodovine sem svojo prvo službo dobil v mladinskem domu in kasneje še v vzgojnem zavodu, kjer sem opravljal vzgojno in izobraževalno delo z otroki in mladostniki z vedenjskimi motnjami. [Niko, 2 leti delovne dobe]

Kot učitelj zgodovine in sociologije sem razporejen na delovno mesto vzgojitelja v skupini za določen čas. Zaradi neustrezne izobrazbe sem se moral vsako leto ponovno prijavljati na razpise za to delovno mesto. [David, 35 let delovne dob]

\section{Menjava službe ali sprememba delovnega mesta}

Menjava službe ali celo karierne poti lahko predstavlja prelomno obdobje v profesionalnem razvoju. Udeleženci so menjavo službe ali delovnega mesta doživljali različno. Glavna predpostavka te perspektive je, da so karierni prehodi dokaj predvidljivi dogodki. Prehodi se največkrat pojavljajo, ko se posameznik stara in v svoji karieri prehaja iz enega razvojnega obdobja v drugo (Sullivan in Crocitto 2007). Prehod iz šole v zaposlitev je prvi večji prehod.

Ob zaključku šolanja dela v moji stroki ni bilo. Ker sem prejemala kadrovsko štipendijo ministrstva, sem se morala zaposliti $v$ šolstvu, da ne bi rabila vračati denarja. Zaradi vsesplošnega pomanjkanja defektologov (danes specialnih in rehabilitacijskih pedagogov) sem službo uspela dobiti v domu. Med delom sem, zato da sem dobila službo za nedoločen čas, opravila ustrezno defektološko dokvalifikacijo. [Helena, 17 let delovne dobe]

Menjava službe ali celo karierne poti lahko predstavlja prelomno obdobje v profesionalnem razvoju. Udeleženci so menjavo službe ali delovnega mesta doživljali različno. Nekateri sploh niso menjali službe ali delovnega mesta.

Iz poklicne biografije je razvidno, da so Nataša, David in Helena prvo zaposlitev dobili na delovnem mestu vzgojitelja otrok s posebnimi potrebami z motnjo v duševnem razvoju. 
Po uspešno končanem strokovnem magisteriju sem po mesecu dni dobila svojo prvo službo $v$ domu. Predvidevam, da bom po koncu tega šolskega leta svojo sanjsko službo izgubila, sama namreč nisem zaposlena za redno. Po dveh letih delovnih izkušenj se bom letos spet preizkusila $v$ iskanju delovnega mesta. [Nataša, 2 leti delovne dobe]

Po opravljeni diplomi na Pedagoški akademiji sem se konec avgusta 1986 zaposlil v domu, kjer sem delal kot vzgojitelj v skupini otrok s posebnimi potrebami, kar opravljam še danes. [David, 35 let delovne dobe]

Tukaj zdaj že sedemnajsto leto delam na delovnem mestu vzgojitelja v skupini. [Helena, 17 let delovne dobe]

Iz poklicne biografije ostalih je moč razbrati, da jim je menjava delovnega mesta ob ostalih okoliščinah predstavljala napor.

Ko je bila hči stara pet mesecev, me je poklicala kolegica iz študija in mi povedala, da imajo razpis. Brez razmišljanja sem poslala prošnjo. Takrat nisem razmišljala, da sem na porodniški in kako bom reševala stvari doma, če službo slučajno res dobim. Kaj preveč nisem upala, saj še nisem imela magisterija iz inkluzije. [Marija, 10 let delovne dobe]

Po vrnitvi delavke s porodniškega dopusta se mi je iztekla pogodba o zaposlitvi. Poučeval sem nemški jezik, in to kot izvajalec individualne strokovne pomoči dijakom $s$ posebnimi potrebami na srednji šoli za gostinstvo in turizem. Preko javnih del sem bil zaposlen $v$ domu kot izvajalec dodatne strokovne pomoči. Sedaj sem zaposlen $v$ domu kot vzgojitelj otrok in mladostnikov s posebnimi potrebami. [Matjaž, 20 let delovne dobe]

Kasneje sem dobila zaposlitev za določen čas na osnovni šoli. Nadomeščala sem porodniško. Po izteku pogodbe za določen čas sem s pomočjo poznanstev dobila službo za določen čas v osnovni šoli. Ko mi je tudi tam potekla pogodba, me je ga. ravnateljica priporočila, da so me sprejeli v domu, kjer sem še danes. [Mojca, 36 let delovne dobe]

Po enem letu dela v vzgojnem zavodu, kjer je bila stanovanjska skupina, sem se ob priložnosti stalne zaposlitve na delovnem mestu svetovalne delavke $v$ domu zaradi primernejšega delovnega časa in oddaljenosti od doma odločila za ponovno vrnitev $v$ dom, kjer delam še danes. [Janja, 9 let delovne dob] 


\section{Prelomni dogodki, krize in druge obremenitve}

Marsikatera poklicna pot je bila zaznamovana s prelomnimi dogodki, krizami in z obremenitvami, ki so pomembno vplivali na osebnost in poklicni razvoj posameznika. Janjo je eden takšnih dogodkov spodbudil, da je dala odpoved in sprejela drugo delo.

Pomemben dogodek je zame predstavljala odpoved v vzgojnem zavodu in sprejem opravljanja dela na delovnem mestu svetovalne delavke $v$ domu. Ko danes pogledam nazaj, vidim, da je $v$ tistem trenutku šlo za premočno navezanost na uporabnike. Takrat sem morala sama sebe prepričati, da bo za uporabnike $v$ vzgojnem zavodu poskrbel nekdo drug in da bom z delom $v$ domu prav tako dobila uporabnike, $\mathrm{ki}$ me bodo rabili. [Janja, 9 let delovne dobe]

Pri Vanji je bil močno prisoten altruizem oz. nudenje pomoči drugim, ki je bil povezan z dogodkom iz prve zaposlitve.

Ob študiju sem opravljala študentsko delo v pisarni izvršitelja, kjer sem $v$ večini primerov sprejemala stranke iz socialno šibkih družin. Otrokoma je želela le najboljše, vendar sta imela luknjasta, umazana oblačila, potožila sta se, da ne želita hoditi v šolo, ker ju vsi zbadajo, da nimata prijateljev in da ju nihče ne mara. Po tem dogodku sem vedela, da sem se odločila za pravilno poklicno pot, saj kot pedagoginja lahko poskrbim ravno za takšne težave otrok in mladostnikov. [Vanja, 2 leti delovne dobe]

Mojci je bilo težko izpostaviti pomemben dogodek, ki bi vplival na njeno poklicno pot, izpostavila je le stalno delovno okolje in zanesljiv dohodek.

Ne morem izpostaviti pomembnega dogodka, ki bi vplival na mojo poklicno pot, ker ga ni. Za to pot sem se odločila, ker je bila tukaj edina možnost, da dobim službo za dalj časa in da se neham potikati po šolah za določen čas. [Mojca, 36 let delovne dobe]

Matjaž in Niko sta spoznala, da sta ob menjavi poklica prepoznala še svoje druge nove sposobnosti.

Pomemben dogodek, ki je vplival na mojo poklicno pot, je bil začetek dela $z$ otroki in mladostniki s posebnimi potrebami v domu. Hitro sem 
ugotovil, da mi delo s to občutljivo populacijo zelo leži in da imam sposobnost nuditi pomoč in podporo otrokom in mladostnikom s posebnimi potrebami, ki ju zelo potrebujejo in za katero so zelo hvaležni. [Matjaž, 20 let delovne dobe]

Delo z otroki z raznimi motnjami me je vedno zanimalo, saj me je mama večkrat vzela zraven v službo v vzgojni zavod ter na razna letovanja, kjer sem lahko take otroke in mladostnike tudi spoznal. [Niko, 2 leti delovne dobe]

David je bil že prvi dan zaposlitve izzvan z neželenim vedenjem mladostnika, s pomočjo katerega je spoznal, da zmore premagovati tudi težke situacije $v$ odnosu do mladostnikov s posebnimi potrebami.

V skupini otrok, ki sem jo prevzel, je bil fant z imenom Franci. Bil je strah in trepet vseh, otrok in zaposlenih. Po eni uspešno rešeni krizni situaciji sva oba izgubila strah in pridobila zaupanje drug v drugega. [David, 35 let delovne dobe]

Za Marijo je bil ključen dogodek, da se je odločila za študij inkluzivne pedagogike, informativni dan na fakulteti.

Ključni dogodek je bil vsekakor informativni dan Pedagoške fakultete v Kopru za študij inkluzivne pedagogike, kjer sem poslušala dr. Oparo, ki je z zanosom in energijo opisoval delo pedagoga z otroki s posebnimi potrebami. Takrat sem se odločila, da tudi sama želim po tej poti. [Marija, 10 let delovne dobe]

Helenina največja izziva sta bila materinstvo in obvladovanje časa.

S tem ko sem postala mama, se zavedam, da nimam več časa samo za otroke v službi, ki sem se jim do takrat 100-odstotno ali še več povečala. Zaradi svojih otok si želim spremeniti službo. [Helena, 17 let delovne dobe]

\section{Razprava}

Rezultati kažejo, da se je večina udeležencev raziskave zaposlila brez ustreznih izobrazbenih pogojev, kar je bilo mogoče zaradi pomanjkanja vzgojiteljev za delo $z$ otroki z motnjo $v$ duševnem razvoju. Večina jih je omenila, da so ob tem zasledovali cilj zaposlitve za nedoločen čas, za izobraževanje so se 
odločili tudi zaradi osebnih okoliščin ali preživetja. Zaradi pomanjkanja izobrazbe in ustreznih izkušenj, številnih zahtev delovnega mesta in pričakovanj se jih je večina vključila v dopolnilna izobraževanja defektologije, specialne pedagogike ali celo $v$ dodaten študijski program inkluzivne pedagogike. En udeleženec se je zaradi pomanjkanja pedagoške izobrazbe vključil v dodiplomsko prekvalifikacijo.

Rezultati raziskave o prvih delovnih izkušnjah pedagoških delavcev (Hanushek 1971 v Atteberry, Loeb in Wyckoff 2015) nakazujejo, da začetne delovne izkušnje (prvi dve leti) precej dobro napovedujejo nadaljnjo uspešnost glede na druge tradicionalne izmerjene značilnosti (delovne izkušnje in usposobljenost, dodatna izobraževanja za pridobitev magistrskega naziva, specialne licence, izbirnost fakultet idr.). Lažje je prepoznati tiste, ki se bodo odlično izkazali, kot pa tiste, ki bodo zelo neučinkoviti.

Raziskava je pokazala, da so med izpostavljenimi dejavniki pri izbiri poklica: zaposlitev za nedoločen čas, družbena pomoč ter altruizem, želja po nudenju pomoči ljudem v stiski ali v težavah. Do podobnih ugotovitev so prišli v primeru izbire učiteljskega poklica, ko so študentje razrednega pouka (Ivanuš Grmek in Javornik Krečič 2005) najpogosteje navajali samouresničitvene razloge in željo po delu z otroki.

Prvo pomembno obdobje, ki ga v svojem modelu profesionalnega razvoja opisuje Fuller (1969 v Javornik Krečič 2008; Veenman 1984; Feiman Nemser in Floden 1986), je obdobje preživetja. V tem obdobju se pojavijo dileme glede posameznikove usposobljenosti, ustreznosti ali profesionalne primernosti. Vsi udeleženci (razen enega) so imeli višje- ali visokošolsko pedagoško izobrazbo, vendar neustrezne smeri, saj razen ene udeleženke ni nihče izpolnjeval pogojev za zasedbo tega delovnega mesta. Veliko udeležencev raziskave se je po šolanju lahko zaposlilo kot vzgojitelji, pa čeprav še niso imeli ustrezne izobrazbe. Ta primanjkljaj so nadomestili pozneje. S prenovo zakonodaje glede izpolnjevanja zaposlitvenih pogojev se je nekaj udeležencev vključilo $v$ dopolnilno izobraževanje defektologije, ostali pa so se pozneje vključili v študij 2. stopnje inkluzivne pedagogike na Pedagoški fakulteti Koper.

\section{Sklep}

Vrednost raziskave je $v$ poglobljenem vpogledu $v$ vzgojiteljeva razmišljanja in doživljanja kariernega prehoda ter razvoja poklicne poti z ovirami na njej. Pokazalo se je, da so za odločitev za karierni prehod v poklic vzgojitelja pomembnejši priložnost za zaposlitev z možnostjo za nedoločen čas, motivacija za izobraževanje in s tem tudi profesionalni razvoj kot pa izpolnjeni formalni pogoji za zasedbo delovnega mesta. 
Mlajši vzgojitelji nekatere socialne situacije zaznavajo in ocenjujejo kot zaskrbljujoče. Občutek, da jih starejši zaposleni ne jemljejo enakovredno, je za njih frustrirajoč. Zaznavajo, da jih sodelavci v določenih primerih nekritično presojajo, zato na delovnem mestu tudi težje izražajo svoje lastne občutke, stališča, vrednote in druga notranja stanja. Pri ugotavljanju, kateri so bili pomembni dogodki, ki so jih na njihovi poklicni poti najbolj obogatili ali jim predstavljali izziv, jih je pet izpostavilo občutke ob srečanju z otroki s posebnimi potrebami, ena udeleženka je kot prelomni dogodek opisala družinske razmere, druga delovne pogoje. Ena udeleženka je zapisala, da se ne spomni nobenega prelomnega dogodka.

Ugotovimo lahko, da so vrednote in osebne okoliščine pomembne za sprejem odločitev in razvoj posameznika predvsem na začetku karierne poti. Kot lahko sklepamo iz stališč sodelujočih, je bila zaposlitev za nedoločen čas prvi pomemben dejavnik za prehod med poklici in nadaljnji profesionalni razvoj. Je hkrati tudi dejavnik, ki na koncu določa uspešnost ali neuspešnost njihove karierne odločitve. Druga dva dejavnika, ki sta bila v stališčih najpogosteje prisotna, sta družbena pomoč in altruizem - torej želja pomagati ljudem $v$ stiski ali v težavah. Kljub temu, da trg dela v vzgoji in izobraževanju predstavlja poseben izziv za profesionalni razvoj, ne preseneča, da veselje do dela z ljudmi s posebnimi potrebami močno dviguje motivacijo za premagovanje naporov pri posameznikovi karierni odločitvi za poklicni prehod.

Naša raziskava je kvalitativna in omejena z majhnim številom udeležencev, zato zbranih podatkov ne moremo posploševati, ampak so rezultati raziskave lahko le indikatorji za morebitne nadaljnje raziskave. Pri raziskavi smo se tudi omejili samo na vzgojitelje, ki delajo z otroki z motnjami v duševnem razvoju v vzgojnem programu domov. Omejitve, povezne z možnostjo pristranskosti udeležencev, nismo mogli izključiti. Glede na to, da so v raziskavi sodelovali vzgojitelji, ki sprva večinoma niso izpolnjevali pogojev za to delo (razen ene vzgojiteljice), bi bilo zanimivo izpeljati raziskavo še s strokovnim kadrom, ki že na začetku svoje profesionalne poti izpolnjuje vse pogoje za to delo. Predvsem bi lahko ugotavljali, kaj vse je pomagalo pri razvoju poklicne identitete, razvijanju občutka za poklicno usmeritev in poklicni prilagodljivosti.

Glede na izbrano raziskovalno metodologijo dovoljenje ali soglasje komisije za etiko ni bilo potrebno.

\section{Literatura}

Atteberry, A., S. Loeb in J. Wyckoff. 2015. »Do First Impressions Matter? Predicting Early Career Teacher Effectiveness.« https://doi.org/10.1177/ 2332858415607834. 
Barabasch, A., in B. Merrill. 2014. "Cross-Cultural Approaches to Biographical Interviews: Looking at Career Transitions and Lifelong Learning."Research in Comparative and International Education 9 (3): 287-300.

Baruch, Y., Y. Altman in R. Tung. 2016. „Career Mobility in a Global Era: Advances in Managing Expatriation and Repatriation. Academy of Management Annals 10 (1): 841-889.

Beehr, T. A. 2014. »To Retire or Not to Retire: That Is Not the Question.« Journal of Organizational Behavior 35 (8): 1093-1108.

Bilgili, T. V., C. J. Calderon, D. G. Allen in B. L. Kedia, B. L. 2017. „Gone with the Wind: A Meta-Analytic Review of Executive Turnover, Its Antecedents, and Postacquisition Performance." Journal of Management 43 (6): 1966-1997.

Brečko, D. 2006. Načrtovanje kariere kot dialog med organizacijo in posameznikom. Ljubljana: Planet GV.

Brown, A., in J. Bimrose. 2014. »Model of Learning for Career and Labour Market Transitions."Research in Comparative and International Education 9 (3): 270-286.

Cencič, M. 2001. »Življenjska zgodovina na pedagoškem področju.« Sodobna pedagogika 52 (2): 50-62.

Cencič, M., in B. Čagran. 2002. »Motivacijski dejavniki izbire študija in poklica vzgojitelja predšolskih otrok.« Sodobna pedagogika 53 (5): 104-122.

Drobnič, J. 2012. »Novi pristopi pri vodenju kariere, ki izhajajo iz teorije socialnega učenja." Šolsko polje 23 (3-4): 13-29.

Edwards, A., in R. Talbot. 1994. The Hard-Pressed Researcher. London in New York: Addison Wesley Longman.

Ellis, A. M., T. N. Bauer, L. R. Mansfield, B. Erdogan, D. M. Truxillo in L. S. Simon. 2015. »Navigating Uncharted Waters: Newcomer Socialization through the Lens of Stress Theory." Journal of Management 41 (1): 203-235.

Fang, R., M. Duffy in J. Shaw. 2011. »The Organizational Socialization Process: Review and Development of a Social Capital Model. « Journal of Management 37 (1): 127-152.

Feiman Nemser, S., in R. E. Floden. 1986. »The Cultures of Teaching. «V Handbook of Research on Teaching, ur. M. Wittrock, 505-526. New York: Macmillan.

Fuller, F. 1969. "Concerns of Teachers: A Developmental Characterization.« American Educational Research Journal 6:207-226.

Gowan, M. 2014. »Moving from Job Loss to Career Management: The Past, Present, and Future of Involuntary Job Loss Research."Human Resource Management Review 24 (3): 258-270.

Graham, R. J. 1989. »Autobiography and Education.«The Journal of Educational Thought 23 (3): 92-105.

Hanushek, E. A. 1971. „Teacher Characteristics and Gains in Student Achievement: Estimation Using Micro Data.« The American Economic Review 61 (2): 280-288. 
Hmelak, M., in J. Lepičnik Vodopivec. 2012. »Preschool Teacher Career and Why Individualse Choose It: Innovative Issues and Approaches in Social Science." Innovative Issues and Approaches in Social Sciences 5 (2): 218-239.

Hom, P., T. W. Lee, J. D. Shaw in J. P. Hausknecht. 2017. »One Hundred Years of employee Turnover Theory and Research.« Journal of Applied Psychology 102 (3): 530-545.

Ivanuš Grmek, M., in M. Javornik Krečič. 2005. »The Reason Students Chose Teaching Professions.« Educational Studies 31 (3): 265-274.

Javornik Krečič, M. 2006. »Učiteljev profesionalni razvoj in njegov pomen za pouk v osnovni šoli in gimnaziji.« Doktorska disertacija, Univerza v Mariboru.

- 2007. »Proučevanje učiteljevega profesionalnega razvoja z metodo poklicne (avto)biografije.« Pedagoška obzorja 22 (1-2): 3-27.

-2008. Pomen učiteljevega profesionalnega razvoja za pouk. Ljubljana: i2.

Javrh, P. 2011. Razvoj učiteljeve poklicne poti. Učno gradivo 1: splošne in andragoške zakonitosti razvoja kariere. Ljubljana: Andragoški center Slovenije.

Kraimer, M., M. Bolino in B. Mead. 2016. »Themes in Expatriate and Repatriate Research over Four Decades."Annual Review of Organizational Psychology and Organizational Behavior 3 (1): 83-109.

Lepičnik Vodopivec, J. 2007. »Razlogi za izbiro poklica vzgojiteljica predšolskih otrok.« Pedagoška obzorja 22 (3-4): 114-126.

Lončar, M., Z. Šuljug Vučica in T. Bubić. 2019. »Teorijsko-metodološki aspekti pristupa životne povijesti u sociologiji.« Revija za sociologiju 49 (3):377-398.

Louis, M. R. 1980. „Career Transitions: Varieties and Commonalities. « Academy of Management Review 5 (3): 329-340.

Merrill, B., in L. West. 2009. Using Biographical Methods in Social Research. London: Sage.

Noble, H., in J. Smith. 2015. »Issues of Validity and Reliability in Qualitative Research.«Evidence-Based Nursing 18 (2): 34-35.

Peeters, J., in M. Vandenbroeck. 2011. »Professionalization, Leadership and Management in the Early Years."V Professionalization, Leadership and Management in the Early Years, ur. L. Miller in C. Cable, 62-76. London: Sage.

Pravilnik o izobrazbi vzgojiteljev in drugih strokovnih delavcev $v$ vzgojnem programu za otroke in mladostnike s posebnimi potrebami. 2015. Uradni list Republike Slovenije, št. 65. https://www.uradni-list.si/1/objava.jsp?sop $=2015-01-2686$.

Sagadin, J. 1991. »Kvalitativno empirično pedagoško raziskovanje.« Sodobna pedagogika 49 (7-8): 344-355.

Pryor, R. G. L., E. N. Amundson in H. E. J. Bright. 2008. »Probabilities and Possibilities.« The Career Development Quarterly 56:309-318.

Savickas, L. M. 2015. Life-Design Counseling Manual. http://www.vocopher.com/ LifeDesign/LifeDesign.pdf. 
Schlesinger, J., in L. P. Daley. 2016. »Applying the Chaos Theory of Careers as a Framework for College Career Centers." Journal of Employment Counseling 53:86-96.

Strokovni svet Republike Slovenije za splošno izobraževanje. 2003. »Navodila h kurikulumu za vrtce v programih s prilagojenim izvajanjem in dodatno strokovno pomočjo za otroke s posebnimi potrebami.« https://www.gov .si/assets/ministrstva/MIZS/Dokumenti/Sektor-za-predsolsko-vzgojo/

Programi/kurikulum_navodila.pdf

—. 2011. »Vzgojni program domov za učence s posebnimi potrebami.« https://www.gov.si/assets/ministrstva/MIZS/Dokumenti/Izobrazevanje -otrok-s-posebnimi-potrebami/Vzgojni-programi/Vzgojni_prog _domov_PP.pdf.

Sullivan, S. E., in A. Al Ariss. 2021. »Making Sense of Different Perpectives on Career Transitions: A Review and Agenda for Future Research.« Human Resource Management Review 31 (1): 100727. https://doi.org/10.1016/j.hrmr.2019 .100727.

Sullivan, S. E., and M. Crocitto. 2007. »Developmental Career Theories.« V Handbook of Career Studies, ur. M. Peiperl in H. Gunz, 283-309. Thousand Oaks, CA: Sage.

Super, D. E. 1957. The Psychology of Careers. New York: Harper.

Štemberger, T., in N. Vesel. 2015. »Kaj poklicni življenjepisi vzgojiteljic odkrivajo o prepletenosti poklica vzgojitelja in ustvarjalnosti?« Revija za elementarno izobraževanje 8 (3): 17-37.

Takeuchi, R. 2010. »A Critical Review of Expatriate Adjustment Research through a Multiple Stakeholder View: Progress, Emerging Trends, and Prospects." Journal of Management 36 (4): 1040-1064.

Terhart, E. 1997. »Professional Development of Teachers: The Situation in Germany.« Prispevek predstavljen na 8th Conference of the International Study Association on Teacher Thinking (ISATT), Kiel, Nemčija, 1.-5. oktober.

Terjesen, S., J. Hessels in D. Li. 2016. „Comparative International Entrepreneurship." Journal of Management 42 (1): 299-344.

Valenčič Zuljan, M. 2001. »Modeli in načela učiteljevega profesionalnega razvoja."Sodobna pedagogika 52 (2): 122-141.

Valenčič Zuljan, M., in D. Blanuša Trošelj. 2014. »Profesionalni razvoj vzgojiteljev z vidika vzgojiteljevih pojmovanj."Andragoška spoznanja 20 (1): 43-60.

Van Dierendonck, D., in G. Jacobs. 2012. "Survivors and Victims: A Meta-Analytical Review of Fairness and Organizational Commitment after Downsizing."British Journal of Management 23 (1): 96-109.

Veenman, S. 1984. »Perceived Problems of Beginning Teachers."Review of Educational Research 54 (2): 143-178.

Vogrinc, J. 2019. »Predgovor.« V Moč pedagoškega dela, ur. Ž. Jakšič Ivačič, [4-5]. Ljubljana: Pedagoška fakulteta. 
Wang, M., in J. Shi. 2014. »Psychological Research on Retirement.« Annual Review of Psychology 65 (1): 209-233.

Zakon o organizaciji in financiranju vzgoje in izobraževanja (ZOFVI-UPB5) 2007. Uradni list Republike Slovenije, št. 16. https://www.uradni-list.si/1/objava .jsp?sop=2007-01-0718.

Zavod Republike Slovenije za šolstvo. 2015. Kriteriji za opredelitev vrste in stopnje primanjkljajev, ovir oz. motenj otrok s posebnimi potrebami. Ur. N. Vovk Ornik. Ljubljana: Zavod Republike Slovenije za šolstvo.

Zimmerman, L. M., in M. A. Clark. 2016. »Opting-Out and Opting-In: A Review and Agenda for Future Research. «Career Development International 21 (6): 603-633.

Zuzovsky, R. 1990. »Professional Development of Teachers: An Approach and its Application in Teacher Training."Prispevek predstavljen na 15. konferenci ATEE, Limerick, Irska.

\section{Factors of a Career Transition to the Profession of an Educator for Working With Children With Special Needs}

In this paper, we present the factors that contributed to a smooth transition into the profession of educating children with special needs and intellectual disabilities. Nine educators participated in a qualitative study using the occupational biography method. Key factors identified in the transition were steady employment, social support, and altruism to help those in need or difficulty. The research showed that there are differences between educators depending on their length of service. Younger educators evaluate and feel a greater influence of factors resulting from certain social situations, while older educators put more emphasis on job security. Some of them have had to upgrade their professional skills by taking additional training in defectology or special education because they have already received educational training. Others enrolled in a bachelor's degree programme in inclusive education.

Keywords: career transition, professional development, educator, child with special needs, biographical methods 